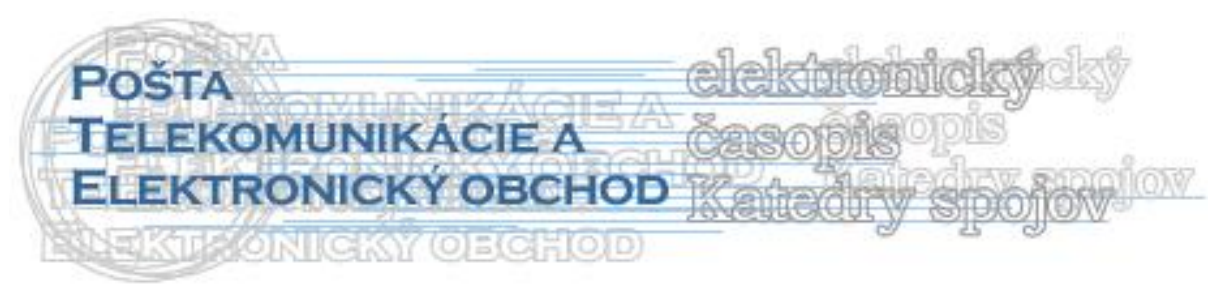

\title{
ÚLOHA KOMUNIKÁCIE PRI ZMENE V PODNIKU
}

\author{
Jaroslava Vidová, Gabriel Kádár, Marek Vida*
}

Úvod

Život podniku je určovaný sústavnými zmenami. Ak chce podnik na trhu prežit', musí ich zvládat', prispôsobovat' svoje štruktúry, procesy, operácie a spôsob myslenia. Jednou z možných príčin krízy podniku je neschopnost' vedenia predvídat' zmeny.

Zložitost' dnešných zmien vyžaduje prístup založený na disciplíne, informovanosti, kompetentnosti l’udí a vhodnej štruktúre. Zmeny sa stávajú častejšími, radikálnejšími a zložitejšími. Každá konkrétna aktivita orientovaná na zmenu musí:

- priniest' očakávaný priamy úžitok,

- posilnit' všeobecnú schopnost' podniku uskutočňovat' zmeny.

Zmena v podniku predstavuje hlavne zmenu riadenia l'udí a aktivít, ktoré treba riadit' a viest' ku konkrétnemu vopred definovanému ciel'u. Prispôsobenie sa zmene je otázkou času a úlohu zohráva aj predchádzajúca skúsenost' so zmenou. Pre zamestnancov, ktorí už získali negatívnu skúsenost', je emocionálne vyrovnanie sa so zmenou zložitejšie. Každý zamestnanec iným spôsobom reaguje na zmenu a iným spôsobom sa vyrovnáva so zmenou.

Realizácia zmeny nie je jednoduchá, vždy je spojená so strachom a neistotou. Najtažšie je presadit' zmenu v podniku v situácii, ked' je v podniku ešte všetko v poriadku, ale manažment už má informácie o blízkosti vážnych problémov, ktoré si vyžadujú zmenu. Dôležitou úlohou manažmentu je vysvetlit' l'ud’om zmenu tak, aby ju chápali ako šancu a začiatok nových príležitostí.

\section{Charakteristika zmien v podnikoch}

Príčinou zmeny v podniku je zistenie určitého problému, ktorý si vyžaduje riešenie. Impulzy vedúce $\mathrm{k}$ zmene môžu byt' dvojaké:

- Vlastná iniciatíva, ktorá je vedená snahou pripravit' zmenu, lebo jej realizácia by znamenala určitý žiadúci pozitívny prínos pre podnik. Pri vlastnej iniciatíve môže dôjst' k:

- spontánnej zmene, ktorá je iniciovaná jednotlivými pracovníkmi alebo skupinami pracovníkov. Je reakciou na nedostatky alebo problémy týkajúce sa pracoviska a môže mat' povahu zlepšenia pracovných alebo technologických problémov, úspory materiálu, zvýšenia bezpečnosti práce.

- programovej zmene, ktorú iniciuje top manažment a môže mat' charakter výskumného a vývojového programu alebo inovácie.

\footnotetext{
* Ing. Jaroslava Vidová, PhD., Ing. Gabiel Kádár, Ing. Marek Vida,

Technická univerzita v Košiciach, Strojnícka fakulta, Katedra manažmentu a ekonomiky, Němcovej 32, 04200

Košice, tel.: +421556023231, fax: +421556023233, e-mail: Jaroslava.Vidova@tuke.sk,
} 
- Vonkajšie podnetyz okolia podniku vyvolávajú potrebu zaoberat' sa určitou zmenou $\mathrm{v}$ tomto prípade, ak je podnik donútený reagovat' na zmeny konkurencie alebo nové situácie na trhu. Vtedy podnik uplatňuje reaktívnu politiku zmien.

Z hl'adiska vplyvu zmeny na vývoj podniku existujú tri typy zmien:

- udržiavacie, ktoré predstavujú zmenu disciplíny a smerujú k lepšiemu využitiu pracovného času,

- zlomové, ktoré umožňujú podniku získat' konkurenčnú výhodu,

- zmeny zamerané na dosiahnutie parity s konkurenciou, ktoré umožňujú držat' krok s konkurenciou.

Zmenu v podniku je možné rozložit' do troch polôh, ako ukazuje obrázok 1 . V prvej polohe zmeny majú manažéri k dispozícií softwarovú podporu, ktorá umožňuje existujúci stav pretvorit' do požadovaného stavu vo viacerých variantoch. Prostredníctvom Activity Based Costing dokážu prepočítat', kol'ko bude každá z navrhovaných zmien stát' a aký bude jej prínos pre podnik. V druhej polohe umožňuje softwarová podpora vytvorit' ekonomické modely, na základe ktorých sa zmeny realizujú. V tretej polohe zmien sa softwarová podpora využíva len obtiažne a do popredia sa dostávajú schopnosti a zručnosti realizátorov zmien.

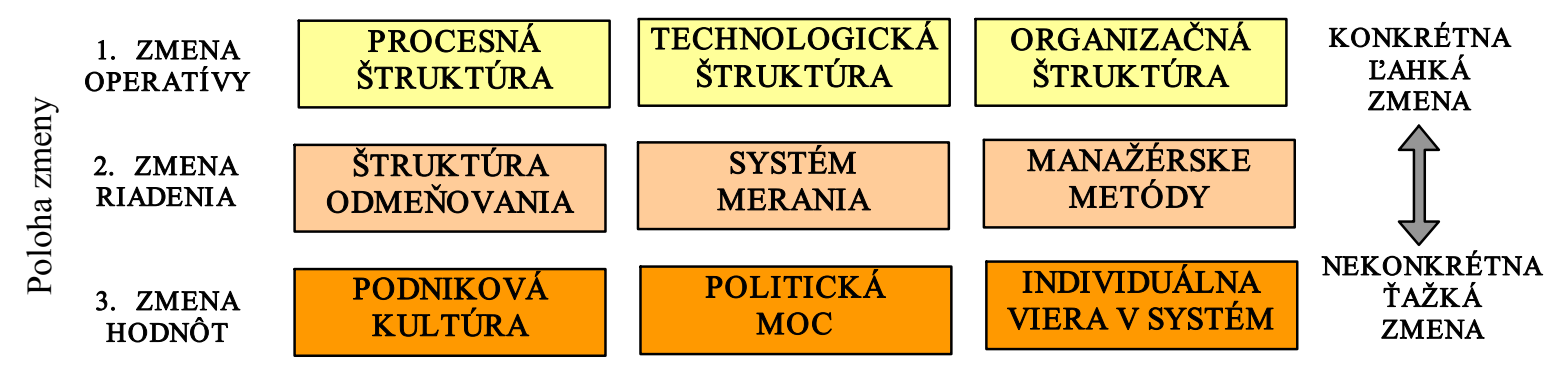

Obr. 1 Závislost' zložitosti zmeny od polohy zmeny

Pri riadení zmeny v podnikoch sa venuje hlavná pozornost' tvrdým prvkom riadenia, ktoré súvisia $\mathrm{s}$ transformáciou podniku a procesov, zatial’ čo jemná stránka zmeny, ktorou sú osobnostné predpoklady zmeny, zostáva na okraji pozornosti, preto z hl'adiska riadenia zmeny je dôležité si uvedomit', že každá zmena má dve časti:

- čast' viazanú priamo na zmenu podniku, ktorá je naplánovaná prostredníctvom projektu zmeny procesov a organizačnej štruktúry,

- čast' viazanú na osobnostnú zmenu, ktorá je súhrnom reakcií, názorov a postojov, ktorými prechádza v priebehu zmeny každý jednotlivec zúčastnený na zmene.

Schopnost' podniku vyrovnat' sa so zmenami je kombináciou flexibility a reaktivity podniku.

- Flexibilita podniku predstavuje požiadavku rýchleho a nízko nákladového prispôsobenia podniku meniacim sa úlohám a podmienkam. Zmeny sa musia aktívne iniciovat' a uskutočnit' tak, aby podnik rýchle využil svoj inovačný náskok.

- Reaktivita podniku predstavuje vlastnost' podniku, prostredníctvom ktorej podnik rýchle a bez vel'kých nákladov sa prispôsobí celkom novým nárokom a situáciám, ktoré vo fáze plánovania neboli predvídatel'né. 
K základným zásadám pre úspešné realizovanie zmien v podniku patria:

- Každá zmena si vyžaduje jasnú víziu. Vízie udávajú smer, ktorým sa má zmena uberat'. Ak vízia chýba, l'udia pôjdu všetkými možnými smermi. Len pre jasne definované predstavy sa dajú l'udia strhnút'.

- Zahrňte čo najskôr vel'kú čast' pracovníkov do prípravy zmeny. Ide o starý, osvedčený princíp "z obetí urobit' spolutvorcov". Ked' sa pracovníci môžu do procesu premeny zapojit', vedia doňho vložit' svoje nápady, zlepšenia a poznatky, a tým ho podstatným spôsobom urýchlia a zlepšia. Majú navyše príležitost' zaujat' stanovisko k novému zžitiu sa s ním a nebudú ho blokovat', alebo sabotovat' $\mathrm{v}$ neskorších etapách. Dobrým spôsobom, ako pracovníkov do procesu premeny zapojit', sú rôzne podujatia pre vel'ké skupiny. Na takýchto podujatiach je možné pracovníkov integrovat' do procesu, informovat' ich o jeho priebehu a vyzbierat' od nich cenné postrehy.

- Proces premeny prebieha zhora nadol. Ak premena nemá podporu manažmentu, vôbec $\mathrm{s}$ ňou nezačínajte! Vedenie podniku musí v každom prípade plne stát' za premenami, musí ich podporovat', komunikovat' a íst' príkladom. Inak ostane pri formálnej zmene, od ktorej sa skôr či neskôr odskočí a veci pôjdu po starom. A pokial' manažment sleduje rozdielne ciele, rozbije sa aj podnikový tím a jednotlivé skupinky budú nezriedka t'ahat' za opačný koniec povrazu.

- Efektívny manažment zmeny musí priniest pracovníkom úžitok. Zmena sa uskutoční len vtedy, ked' sa očakáva úžitok, alebo je snaha odvrátit' hrozbu. Pracovníkom je potrebné ukázat' prednosti zmeny a jasne ich komunikovat'. O čo väčší úžitok prinesie zmena pracovníkom, o to motivovanejšie sa do nej pustia. Nátlak ako nástroj motivácie nedokáže vyvolat' žiadne nadšenie pre zmenu.

- Od začiatku podrobne informujte l'udí. Skoré a dôkladné informácie sú dôležitým základom pre všetky zmeny. Len takto sa dokážu minimalizovat' obavy a zákulisné klebety. Nejeden odpor voči premene vznikol následkom nedostatočných informácií - o tom, čo sa bude diat', ktorých l'udí to postihne (a ktorých nie), ako budú zmeny prebiehat' a čo nastane, ked' skončia. Informujte l'udí aj o čiastkových výsledkoch procesu premeny a o každom viditel'nom úspechu. Bude ich to motivovat' vydržat' až do konca.

- Vytvorte individuálne riešenia pre tých, ktorých zmeny postihnú. Pri každej organizačnej zmene sú vít'azi a porazení. $\mathrm{V}$ priebehu zmien totiž prichádza $\mathrm{k}$ presunu moci a kompetencií. Pre porazených v takomto prípade treba vymysliet' individuálne riešenia, $v$ niektorých prípadoch bude treba siahnut' aj po tvrdých opatreniach.

- Zmena si vyžaduje pravidelnú reflexiu. Kto nereflektuje proces zmeny, riskuje jeho zaviaznutie na mŕtvom bode. Každý proces premeny sprevádzajú neistoty, nepredvídatel'nost', odpor a pochybnosti. Len pravidelné obdobia reflexie a zist'ovanie, na akom stupni sa proces zmeny nachádza, udržiava zmenu v správnom smere. Na to sú najlepšie externe moderované workshopy, kde sa riešia prípadné t’ažkosti ešte skôr, než sa na nich proces zmeny zastaví.

- Manažment zmeny potrebuje plánovanie a štruktúru. Len precízne plánovanie a jasná projektová štruktúra dokážu doviest' proces väčšej premeny $\mathrm{k}$ úspechu. Pre vel'ké zmeny je potrebné vytvorit' samostatnú architektúru, v ktorej sa koordinujú jednotlivé opatrenia, kontrola a práca projektových skupín. Okrem plánovania je potrebná aj ochota otvorene sa zaoberat' novým vývojom situácie.

- Zorganizujte čo najskôr prvé viditel'né úspechy. Každý projekt premeny si vyžaduje priaznivé a nápomocné prostredie. Prvé kroky by nemali byt' príliš 
vel'ké. Prvé úspechy totiž motivujú zamestnancov podniku a odzbroja protivníkov zmeny. Možno povedat', že malé úspechy vedú k vel'kým úspechom.

\section{L’udia a komunikácia v procese zmeny v podniku}

Proces zmeny sa stáva trvalým procesom, ktorý je bezprostredne zviazaný s l'ud’mi. $\mathrm{V}$ procese zmien ide o uvol'nenie vnútornej sily l'udí a ich nasmerovanie k spoločnému ciel'u. Všetko ostatné sú len metódy, techniky a postupy.

Niektorí zamestnanci vítajú zmenu, ako novú výzvu a únik pred stereotypným spôsobom života, väčšina zamestnancov sa jej však viac či menej bráni. Zmeny sú doprevádzané strachom, hnevom, úzkost’ou, sklamaním alebo nenávistou. Vzniká tak odpor proti zmenám, ktorý je však prirodzeným javom.

Napriek tomu, že väčšina l'udí zaujme voči zmenám negatívne postoje správania, je tiež pravdou to, že túžba po nových poznatkoch tvorí základ väčšiny l’udského správania. Táto skutočnost' pomáha prekonat' odpor voči zmene. Zamestnanci prijímajú zmeny troma spôsobmi:

- poddajnost', alebo „rob to, pretože ti to hovorím,“

- identifikácia, alebo „rob to, pretože to robím aj ja,“

- vnútorné uspokojenie, alebo „rob to, pretože to stojí za to.“

O úspechu alebo neúspechu zmeny v podniku rozhoduje dôvera l'udí k názorovým vodcom. Jedným z najdôležitejších prístupov, ako možno zmenu zaviest' vhodným spôsobom v podniku a prekonat' respektíve znížit' pritom odpor zamestnancov je efektívna komunikácia a výchova zamestnancov.

Dôležité je povedat' zamestnancom o zmene predtým, ako sa začne. Dat' im príležitost' prekonzultovat' zmenu, klást' otázky a vyjadrit' znepokojenie a otvorit' komunikačné kanály. Výchova a komunikácia sú zvlášt' užitočné vtedy, ked’ je informácií nedostatok alebo sú nepresné a pomáhajú zamestnancom pochopit', prečo je zmena potrebná a umožňujú vyhnút' sa niektorým príčinám odporu pochádzajúceho z nedorozumení a rôznych hodnotení situácie. Akýkol'vek program, ktorý má za úlohu zlepšit' vzdelávanie a komunikáciu, (napríklad diskusie vo dvojiciach, skupinové stretnutia a prezentácie, interné oznámenia, správy, obežníky), musí byt' založený na vzájomnej dôvere. Nemôže to byt' vzt'ah chápaný ako „oni nám hovoria, prikazujú.“

Skúsenosti ukazujú, že úspech komunikácie pri zmene v podniku nezávisí len od dobre vypracovaného manuálu realizácie zmeny, ale predovšetkým od prístupu manažérov $\mathrm{k}$ riešeniu existujúcej situácie, od schopnosti l'udí spolupracovat' $\mathrm{v}$ stresovej situácii, od rýchlosti rozhodovania a podnikovej kultúry. Základ komunikácie v procese podnikovej zmeny leží v internej komunikácii podniku.

V uskutočňovaní zmien sú všeobecne najúspešnejšie podniky, kde každý jednotlivec chápe význam a silu informácie. Rovnako chápe svoj osobný význam v procese zmien a chápe význam a úlohu informácie v rámci podnikovej štruktúry. Dôležité je uvedomit' si potenciál možného negatívneho vplyvu procesu zmeny na zákazníkov, obchodných partnerov, štátne či regulačné inštitúcie alebo celospoločenské otázky. Reputácia by mala byt' pre každého zamestnanca vecou osobnou, spoločnou pre celý podnik, bytostne spätou s jeho pôsobením v podniku.

Príčiny neúspechu realizácie podnikovej zmeny väčšinou plynú z podcenenia sily a významu informácie a podcenenia nevyhnutnosti obojsmerného obehu relevantných 
informácií v internej komunikácii podniku. Príklady, ktoré driemu v podniku a spomal’ujú jeho reakčnú schopnost', netreba dlho hl'adat':

- Nezdravá rivalita či nezhody medzi jednotlivými oddeleniami alebo jednotlivcami, ktoré vyúst'ujú až do neposúvania informácií.

- Spory na pracovisku.

- Strach z reakcie nadriadeného na posunutie negatívnej informácie v rámci podniku, ktorá má vplyv na zhoršenie výsledkov oddelenia.

- Apatia $\mathrm{k}$ problému, ktorý sa zamestnanca priamo netýka, pretože sa týka "len" podniku - absencia identifikácie zamestnanca s podnikom.

- Neochota vedenia prijat' zodpovednost' za závažné rozhodnutia v čase zmeny.

\section{Metódy a techniky efektívnej komunikácie v procese podnikovej zmeny}

Účinnou metódou na úspešné zvládanie komunikácie v priebehu realizácie zmeny v podniku sa ukazuje tréning komunikácie simulačným spôsobom. Ten na jednej strane preverí aktuálnost' a fungovanie postupov podnikovej komunikácie. Na druhej strane zvýši porozumenie medzi manažérmi komunikácie, ktorí sú zodpovední za externú komunikáciu a obvykle komunikáciu počas zmeny koordinujú, a manažérmi na výrobných, prevádzkových a obchodných úsekoch podniku, ktorí sa na riešení situácií podiel'ajú.

Princíp tréningu je vel'mi jednoduchý - výrazné udalosti, ktoré človek na vlastnej koži prežije, nezabudne. Naopak, d’alej formujú jeho budúce správanie. Zážitková metóda tréningu verne imituje možné scenáre vývoja situácie vrátane skutočných reakcií médií, štátnych orgánov či dôležitých názorových vodcov a zamestnancov. Zmiešané tímy tak počas dňa prediskutúvajú rôzne prístupy $\mathrm{k}$ riešeniu - musia robit' rozhodnutia manažérske aj komunikačné, sú pod časovým tlakom a za výsledok nesú aj zodpovednost'. Súčast’ou každej prípadovej štúdie je aj otázka, ako sa dalo konfliktu predíst'.

Najdôležitejším výstupom je zmena $\mathrm{v}$ myslení a prístupe manažérov. Po takomto tréningu si zvyčajne už nemyslia, že negatívny článok je výsledkom slabej práce komunikačného oddelenia. Uvedomujú si, že negatívny článok je niekedy len výsledkom fungovania celého podniku. Po tréningu si lepšie vedia predstavit', kde problém vzniká, ako sa môžu naučit' dobre predvídat' a spolu so svojimi kolegami otvorene komunikovat' o riešení problému. Tak sa zvýši porozumenie medzi manažérmi a komunikátormi. Zvýši sa aj potenciál zvládnutia procesu zmeny.

K základným technikám efektívnej komunikácii v procese realizácie zmien v podniku je možné zaradit':

- správne formulovanie ciel'ov,

- urovnanie konfliktu - kompromis,

- uskutočnenie zmien metaforami,

- reframing,

- asertívnu komunikáciu.

\subsection{Správne formulovanie ciel'ov}

Napísané ciele a želania nie sú v konečnom dôsledku často ničím iným ako neživou abstrakciou. Kto si dokáže plasticky predstavit' to, čo by chcel vidiet', počut' a cítit', získa tým konkrétny východiskový bod pre svoju energiu.

Pre správne formulovanie ciel'ov potrebných na dosiahnutie želanej zmeny je vhodné, aby manažéri pri komunikácii so zamestnancami podali ciele nasledovne: 


\section{Orientácia na ciel’a nie na príčinu}

Pri t’ažkostiach alebo v čase zmien sa často zamestnanci uchyl’ujú k tomu, že vinu za rôzne problémy prisudzujú iným. Prenášajú zodpovednost' za riešenie problémov a za vlastné chyby a pocity na iných, väčšinou svojich nadriadených. Komunikáciu orientujú skôr na príčinu, ako na ciel'. Úlohou manažérov je v tomto prípade dokázat' nasmerovat' komunikáciu o zmene tak, aby diskusia o nej bola orientovaná na ciel'. Ciel'ovo orientované myslenie je plodnejšie a uspokojujúcejšie a podporuje osobnú zodpovednost'.

Komunikácia orientovaná na ciel’ má byt’ zameraná predovšetkým na:

- výsledok,

- spôsob ako výsledok dosiahnut,

- dispozičné možnosti,

- odozvu.

Je dôležité vyhnút' sa komunikácii orientovanej na príčinu, ktorá chápe zmenu ako problém, hl'adá dôvody pre jej uskutočnenie, hl'adá prekážky pre jej uskutočnenie a vyvodzuje zo zmeny dopredu neúspech a skepsu.

\section{Správne dimenzovanie cielov - umocnenie a uzemnenie}

Pri zavádzaní zmeny a stanovení ciel'a na jej dosiahnutie môžu prispiet' dva dôvody $\mathrm{k}$ tomu, že stanovený ciel' a zmena nebudú dosiahnuté:

- ciel' sa zdá byt' triviálnym a málo namáhavým a preto je mu venovaná len polovica pozornosti alebo je ciel' len malou prioritou,

- ciel' je dostatočne podnetný, ale nedosiahnutel'ný. Taký ciel' často spôsobuje frustráciu. V tomto prípade je potrebné pôvodný ciel' rozdelit' do vhodných čiastkových ciel'ov.

\section{Formulovanie motivujúcich ciel'ov}

Pri formulovaní motivujúceho ciel’a by mal manažér postupovat' motivujúco a v zmysle hesla PUKUB:

- P - pozitívne - Podvedomie pracuje najúčinnejšie, ked' sa môže orientovat' na jasné pozitívne predstavy. Potom môže vyhodnotit' pokroky $\mathrm{v}$ smere ciel' a medzitým, ak je to potrebné, zmenit' kurz. Neurčité, všeobecne formulované ciele nedodávajú jednoducho podvedomiu žiaduce navigačné údaje.

- U - úspech - Určit' kritéria pre určenie dosiahnutia stanoveného ciel'a.

- K - kontrola - Zabezpečit' kontrolu nad dôležitými faktory potrebnými pre dosiahnutie ciel'a. Najsl'ubnejšie ciele pre dosiahnutie úspechu sú tie, nad ktorými má manažér d’alekosiahlu kontrolu.

- U - účinky - Motiváciou pre vynaloženie času, nákladov a snahy na dosiahnutie ciel'a je súlad stanoveného ciel'a s hodnotovými predstavami zúčastnených. Ak ciel' nie je logický, alebo je v rozpore s osobnostou či pracovnou pozíciou konkrétnej osoby, snaha o jeho dosiahnutie je nízka.

- B - budúcnost - Schopnost' predvídat' budúcnost' a vytvárat' jednotlivé kroky, ktoré umožnia dosiahnutie ciel'a.

\section{Predvídanie budúcnosti}

Je potrebné vypracovat' vhodné a dosiahnutel'né plány, predvídat' problémy a vyvinút' možné východiská. Je možné odhadnút' predpokladané výsledky budúcich rozhodnutí, eventuálne spravit' potrebné opravné opatrenia s ohl'adom na ciele a záujmy. 


\subsection{Urovnanie konfliktu - kompromis}

Pri tomto spôsobe komunikácie je vhodné pre manažérov použit' techniku kompromisu, ktorá je zárukou spokojnosti na oboch stranách. V medzil'udských vzt'ahoch patrí $\mathrm{k}$ jedným $\mathrm{z}$ najefektívnejších riešení. Jedná sa o schopnost' rešpektovat toho druhého a vediet' ho počúvat'. V prípade, že chce manažér presadit' nejakú zmenu, musí byt' pripravený taktiež v niečom ustúpit', pretože pre správne a úspešné zavedenie zmeny je dôležitý súhlas, pochopenie a spokojnost' oboch strán. Pokial' nie je $\mathrm{v}$ hre sebaúcta, je vhodné $\mathrm{v}$ rámci presadenia ponúkat' pre obe strany prijatel'ný kompromis.

\subsection{Uskutočnenie zmien metaforami}

Pri tejto technike je úlohou manažérov citlivo a účinne vzbudit' emócie a „zapálit‘“ zamestnancov pre zmenu. Priblížit' ich kželanej predstave a ciel'om prostredníctvom kreatívnych metafor. Tie často umožňujú nové pohl'ady, ktoré sa nedajú vytvorit' priamymi metódami ako sú vysvetlenia, požiadavky, návrhy, rady alebo inštrukcie. Metafory účinkujú, pretože sa orientujú na podvedomie, pomáhajú odstránit' blokujúce predstavy a realizovat' želané zmeny správania. Návrh, ktorý je zabalený do metafory, má u l'udí, ktorí sú voči zmenám skôr nedôverčiví, väčšiu šancu, byt’ nimi akceptovaný.

\subsection{Reframing}

Technika reframingu predstavuje prekonanie blokád v myslení zmenou zmyslu kontextu. Myslenie zamestnancov, ale aj manažérov niekedy uviazne, lebo sú schopní vidiet' nejakú situáciu alebo objekt súvisiaci so zmenou len v jednom určitom kontexte. Ak je objekt vnímaný, zaradený do určitej triedy, je t’ažké predstavit' si tento objekt aj ako súčast' inej triedy. Tým vlastne príslušnost' $\mathrm{k}$ nejakej triede určuje realitu. Vd'aka reframingu a zmene zmyslu sa dá predstavit' alternatívna príslušnost' $\mathrm{k}$ triede a môže sa tak vyhnút' blokujúcej fixácii reality. V tomto prípade je úlohou manažérov vediet' podat' udalost' alebo situáciu, ktorá súvisí so zmenou aj inák tak, aby sa rozvinuli nové pocity a aby sa našli nové, pozitívnejšie možnosti konania. Manažér zanechá doterajší vzorový rámec (anglicky frame) alebo kontext a zamení ho za iný. Reframing môže úplne zmenit' spôsob, akým sa zobrazuje problém a môže viest' k novým spôsobom správania a riešení. Účinok sa pritom nemusí dostavit' bezprostredne. Často stačí, že zamestnanec opustí zaužívané spôsoby chápenia, aby bol prístupný novým začiatkom.

\subsection{Asertívna komunikácia}

Asertívne komunikujúci manažér dokáže presne a jasne definovat' čo chce, alebo čo nechce, ako situáciu vidí, čo si o nej myslí, ako ju prežíva, nesnaží sa nič skrývat', nič naznačovat', je otvorený a úprimný. Je však potrebné upozornit' na to, že úprimnost' nemožno vyjadrovat' do dôsledkov a vo všetkých situáciách. Je potrebné rešpektovat' slušnost', galantnost' a ohl'aduplnost'. Nie je možné vždy povedat' za každých okolností, čo si myslíme o zamestnancovi. Sú situácie, kedy je nutné pravdu skrývat', aby sa zamestnancovi neubližilo.

Asertívne komunikujúci manažér trvá na svojich právach, ale robí to spôsobom, ktorý nepoškodzuje práva iných. Má pozitívny postoj $\mathrm{k}$ zamestnancom a primerané sebavedomie. Rešpektuje druhú stranu, ctí jej dôstojnost', práva a dokáže počúvat' iných. Je ochotný zmenit' svoj názor, priznat' svoju chybu, pristúpit' na kompromis, pretože považuje zamestnancov za 
rovnoprávnych. Je ochotný ustúpit' v rámci recipročnej dohody. Dokáže povedat' nie, dokáže kritizovat' tak, aby to bolo prijatel'né a taktiež prijíma vlastnú kritiku.

Asertívna komunikácia je kl’udná, manažér celkovo pôsobí uvol’neným dojmom. Teda tak, ako jeho verbálny, tak i neverbálny prejav je bez akéhokol'vek napätia a nervov. Tón hlasu je primerane hlasitý, zrozumitel'ný, tempo reči je rovnomerné a neustále udržuje očný kontakt. Asertívne komunikujúci manažér vytvára okolo seba pohodu. Srší z neho istota, dokáže počúvat' a byt' empatický. Je väčšinou príjemným a komunikatívnym spoločníkom. Ked' sa mu niečo nepodarí, neviní zo svojho neúspechu druhých ani nepresvedčuje seba samého, že to bol vlastne úspech. Vie rozpoznat' a ubránit' sa manipulácii a rešpektuje morálne zásady.

\section{Záver}

Komunikácia a schopnost' efektívne komunikovat' v súčasnej dobe patrí k najdôležitejším schopnostiam každého manažéra. Každodenné aktivity manažérov zahŕňajú neustálu komunikáciu s podriadenými, zákazníkmi. Vrcholoví manažéri venujú komunikácii viac ako $75 \%$ svojho času. Prostredníctvom komunikácie sa pracovníci v podniku spájajú na dosiahnutie spoločného ciel'a. Skupina pracovníkov bez komunikácie nemôže fungovat', pretože by sa nemohla koordinovat' ich činnost'. V prípade porozumenia a efektívnej komunikácie je možné vhodne usmerňovat' jednotlivcov alebo skupiny, modifikovat' ich správanie s ciel'om dosahovat' efektívne zmeny, zabezpečit' splnenie príslušných plánov, ciel'ov a úloh.

Ked’že je snahou, aby zmeny v podniku viedli k pozitívnym výsledkom je nevyhnutné, aby sa zmena stala dôležitou súčast’ou manažérskej práce. Manažéri musia vycítit' jej potrebu včas, čo najrýchlejšie ju zaviest' do praxe a eliminovat' pri tom odpor voči zmene, ktorý je jej prirodzeným javom.

\section{Literatúra}

[1] ADAIR, J.: Efektivní komunikace, Alfa Publishing 2004, Praha, ISBN 80-86851-10-9.

[2] DEVITO, A.J.: Základy mezilidské komunikace, Grada Publishing 2001, Praha, ISBN 80-7169-988-8.

[3] FERJENČÍK, J.: Komunikácia v organizáciách, Ekonóm 2001, Bratislava, ISBN 80-225$1415-2$.

[4] MIHOK, J. - VIDOVÁ, J.: Riadenie krízy na pracovisku. In: Medzinárodná vedecká konferencia „Manažment l'udského potenciálu v podniku“, KPH Drevárska fakulta TU Zvolen, Zvolen 2006, ISBN 80-228-1585-3, s. 125-130.

[5] MIHOK, J. - VIDOVÁ, J.: Riadenie podniku v kríze. Košice : SjF TU v Košiciach, 2006. ISBN 80-8073-533-6.

[6] MIKULAŠTÍK, M.: Komunikační dovednosti v praxi, Grada Publishing 2003, Praha, ISBN 80-247-0650-4.

\section{Grantová podpora}

Príspevok bol pripravený $v$ rámci riešenia grantovej úlohy VEGA 1/2198/05 Využitie internetového marketingu ako nástroja pre zvýšenie konkurencieschopnosti domácich subjektov po vstupe SR do EÚ. 